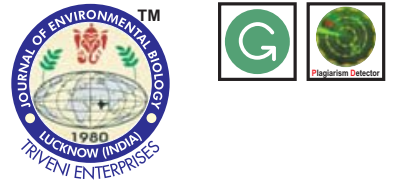

\title{
Association of leaf micro-morphological features with sterility mosaic disease resistance in pigeonpea
}

Authors Info

P.G. Patil ${ }^{1,2 *}$, H.E. Shashidhar ${ }^{2}$, M. Byregowda', G.A.M. Reena ${ }^{2}$, T.H. Ashok', H.V.V. Swamy', H.K. Ramappa and J. Babu'

${ }^{1}$ Division of Plant Biotechnology, Indian Institute of Pulses Research, Kanpur-208 024, India

${ }^{2}$ Department of Plant Biotechnology, AICRP on Pigeonpea, University of Agricultural Sciences, GKVK, Bengaluru -560065 , India

${ }^{*}$ Corresponding Author Email : patilbt@gmail.com

Key words

Discriminant analysis, Micro-morphological traits, Pigeonpea,

Sterility mosaic disease

Publication Info

Paper received : 18.02 .2016

Revised received : 25.07 .2016

Re-revised received : 23.11 .2016

Accepted : 01.12.2016

\section{Abstract}

Aim: Sterility mosaic disease (SMD) is one of the major disease in pigeonpea, which causes heavy yield losses upto $95 \%$ in India. The disease is caused by pigeonpea sterility mosaic virus (PPSMV) and transmitted by eriophyid mite (Aceria cajani). The occurrence of five different isolates of virus were reported, which are transmitted by single biotype of mite. Therefore, the present study was carried out to identify important leaf structural features of pigeonpea that impart resistance to mite vector, there by helping in broad based resistance breeding against SMD pathogens.

Methodology: Twenty three extreme pigeonpea genotypes showing resistance (9) and susceptible (14) reaction to SMD were selected from seventy genotypes, which were screened for Bengaluru isolate of SMD. Data were recorded on twelve important leaf micro-morphological traits including trichome number and length on the upper and lower surface of leaf in cultivars and wild belonging to resistance and susceptible groups. The promising leaf features which were significantly differing, correlating and with higher discriminant function were identified from the resistant and susceptible groups of cultivars, wild and across using three statistical methods such as paired t-test, correlation and discriminant analysis.

Results: In cultivars, specific leaf area (SLA) and specific leaf weight (SLW), in wild trichome number on upper surface (TNUS) and lower surface (TNLS) of leaf, and for across genotypes trichome length on lower surface of leaf (TLLS) and SLA were found most informative. Association of these traits across the genotypes revealed that TNUS, TNLS, TLLS and SLW were significantly and negatively associated with percent disease incidence (PDI). Considering these traits, discriminant functions were developed to identify resistant genotypes. Scatter plots based on SLA and SLW classified pigeonpea cultivars with $100 \%$ accuracy, TNLS and TNUS classified wild genotypes with $83.3 \%$ accuracy, TLLS and SLA classified both cultivar and wild with $76.6 \%$ accuracy in relation to disease response.

Interpretation: The leaf micro-morphological features such as TNUS, TNLS, TLLS, SLA and SLW were found significantly differing, correlating and with higher discriminant function in relation to $S M D$ disease response. These traits are possibly involved in bringing vector mediated resistance to SMD.

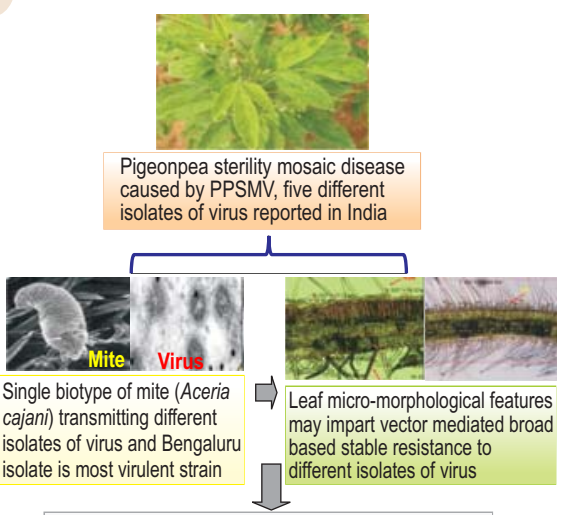

A set of cultivars and wild pigeonpea genotypes were selected in response to SMD resistance and observations were recorded on twelve leaf micro-morphological traits including trichomes

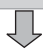

Through t-test, correlation and discriminant analysis, identified TNUS, TNLS, TLLS, SLA and SLW were significant, negatively correlated and having high discrimination power in relation to SMD incidence

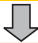

Breeding for such leaf trait is very important in broad based stable resistance to SMD 
Introduction

Pigeonpea (Cajanus cajan) is a major grain legume crop of India and other developing countries of Asia, Africa and Latin America. Globally, it is cultivated in an area of about 6.23 mha with annual production of $4.85 \mathrm{mt}$. India accounts for $90 \%$ of the global production with area $4.65 \mathrm{mha}$ and production of $3.29 \mathrm{mt}$ (FAOSTAT, 2014). Although, India leads the world both in area and production, its productivity is lower $\left(700 \mathrm{~kg} \mathrm{ha}^{-1}\right)$ than the world average. This is attributed to exposure of this crop to various biotic and abiotic stresses (Gnanesh et al., 2011). Among the biotic stress, pigeonpea sterility mosaic disease (SMD) is of main economic concern and has witnessed yield losses up to 95 $\%$ in India (Reddy and Nene, 1981). The disease is caused by pigeonpea sterility mosaic virus (PPSMV) and transmitted by eriophyid mite (Aceria cajani Channabasavanna) (Kumar et al., 2003)

The mite vector is highly host specific, natural host range of SMD is restricted to pigeonpea and few of its wild relatives (Reddy et al., 1998). Pigeonpea has adopted diverse mechanisms to SMD resistance. Control of this disease by chemical methods is not economical and non-ecofriendly. Therefore, breeding for SMD resistant varieties is the best strategy for reducing crop losses. A comprehensive variability study revealed plasticity in sterility mosaic pathogen and not on mite vector. The occurrence of five different isolates of virus were reported and three of them have been well characterised viz., Bengaluru, Patancheru and Coimbatore isolates. The Patancheru and Coimbatore isolates are mild strains, while Bengaluru isolate is the most virulent strain (Kulkarni et al., 2003). Very few of the pigeonpea genotypes were found to have multienvironment (broad based) stable resistances to different isolates of sterility mosaic pathogens (Sharma et al., 2015). Identification of pigeonpea sources that possess broad-based resistances is most vital to enhance the pigeonpea productivity in India. Since, these can be used as potential resistant donors for breeding high yielding resistant varieties. Therefore, the present study was carried out to identify important leaf structural features of pigeonpea that impart vector based resistance to SMD.

Leaf morphological features can have positive or negative influence on herbivores, as well as on their natural enemies (Krips et al., 1999). Among various leaf features, trichomes and trichome exudates on leaf surfaces play an important role in the host selection process by herbivores (Bernays and Chapman, 1994). Peter et al. (1995a) reported that type of trichomes and their orientation, density and length play an important role in reduced insect damage in many crops Similarly, importance of anatomical studies has been reported in many plants (Durmuskahya et al., 2015; Gucel, 2015). In the present study various micro-morphological traits of leaves in resistant and susceptible pigeonpea genotypes were evaluated. The degree of association of these leaf features with SMD resistance were analysed.

\section{Materials and Methods}

Plant material and leaf micro-morphological study: Twenty three extreme pigeonpea genotypes showing resistance (9) and susceptible (14) reaction to SMD were selected from seventy genotypes (Table1), which were screened for Bengaluru isolate of SMD during Kharif-2013 (Patil et al., 2015). The data on twelve leaf micro-morphological traits such as leaf thickness (LT), upper epidermal thickness (UEPT), lower epidermal thickness (LEPT), upper cuticle cell wall complex (UCWC), lower cuticle cell wall complex (LCWC), trichome number on upper surface of leaf (TNUS), trichome number on lower surface of leaf (TNLS), trichome length on upper surface of leaf (TLUS) and trichome length on lower surface of leaf (TLLS), leaf chlorophyll content (LCC), specific leaf area (SLA) and specific leaf weight (SLW) were taken for these twenty three selected set of pigeonpea genotypes (Patil et al., 2015).

Data analyses : For statistical analyses, data on few of the traits such as per cent disease incidence (PDI) and trichome numbers on leaf surfaces were curated with arcsine and square root transformations. Paired t-test assuming unequal variances was used to compare mean values for resistant and susceptible groups in cultivars, wild and combined. Analysis was performed using Microsoft Excel version 8.0. Pearson correlation coefficients were calculated to compare PDI with all 12 leaf micromorphological trait mean values. Various leaf parameters were analysed with discriminant analysis using SPSS vs 16.0. For discriminant analysis, dependent variables (y) were resistant $(0)$ and susceptible (1) groups. 0 and 1 indicates SMD incidence $<10$ and $>30 \%$, respectively. Independent variables $(x)$ were all 12 micro-morphological traits employed. Finally, based on t-test, correlation and discrimination analysis promising micromorphological trait were identified and used for cluster analysis using package STATISTICA vs 8.0 (Statsoft Inc., Tulsa, OK, USA). The squared euclidean distance based hierarchical clustering was used to construct a dendrogram.

\section{Results and Discussion}

Most of the phloem-feeding insects are known to transmit more than a 100 different plant viruses (Brault et al., 2010). Due to high mutation rate observed for viral genomes, it is relatively easy for plant viruses to overcome the resistance of plants (Harrison, 2002). Therefore, it becomes an attractive strategy to search for resistance against the vector insect rather than for the resistance against each individual virus (Chen et al., 2012).

Comparison of leaf micro-morphological features: The leaf epidermal features represent the first barrier for arthropod herbivores (Fordyce and Agrawal, 2001). In-order to identify micro-morpholical traits closely associated with vector mediated resistance to SMD. Leaf anatomical traits were measured and analysed in relation to PDI (Fig. 1). The mean values of micromorphological traits for cultivars (11) and wild (12) species were compared (Table 1). Except for TNUS (24.64) and TNLS (28.42), 


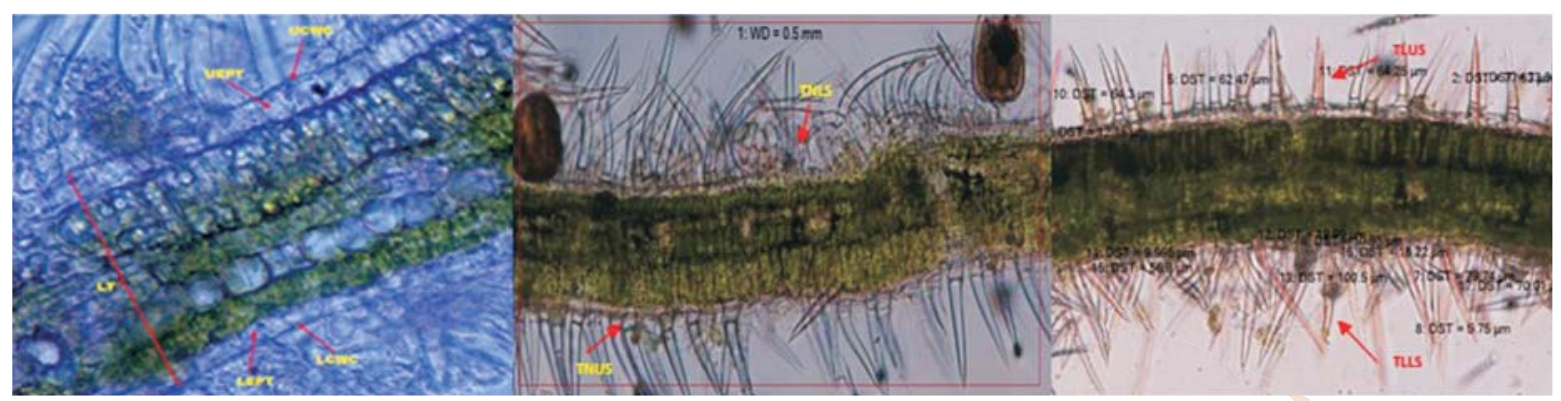

Fig. 1 : Leaf cross sections showing various micro-morphological features studied in pigeonpea genotype

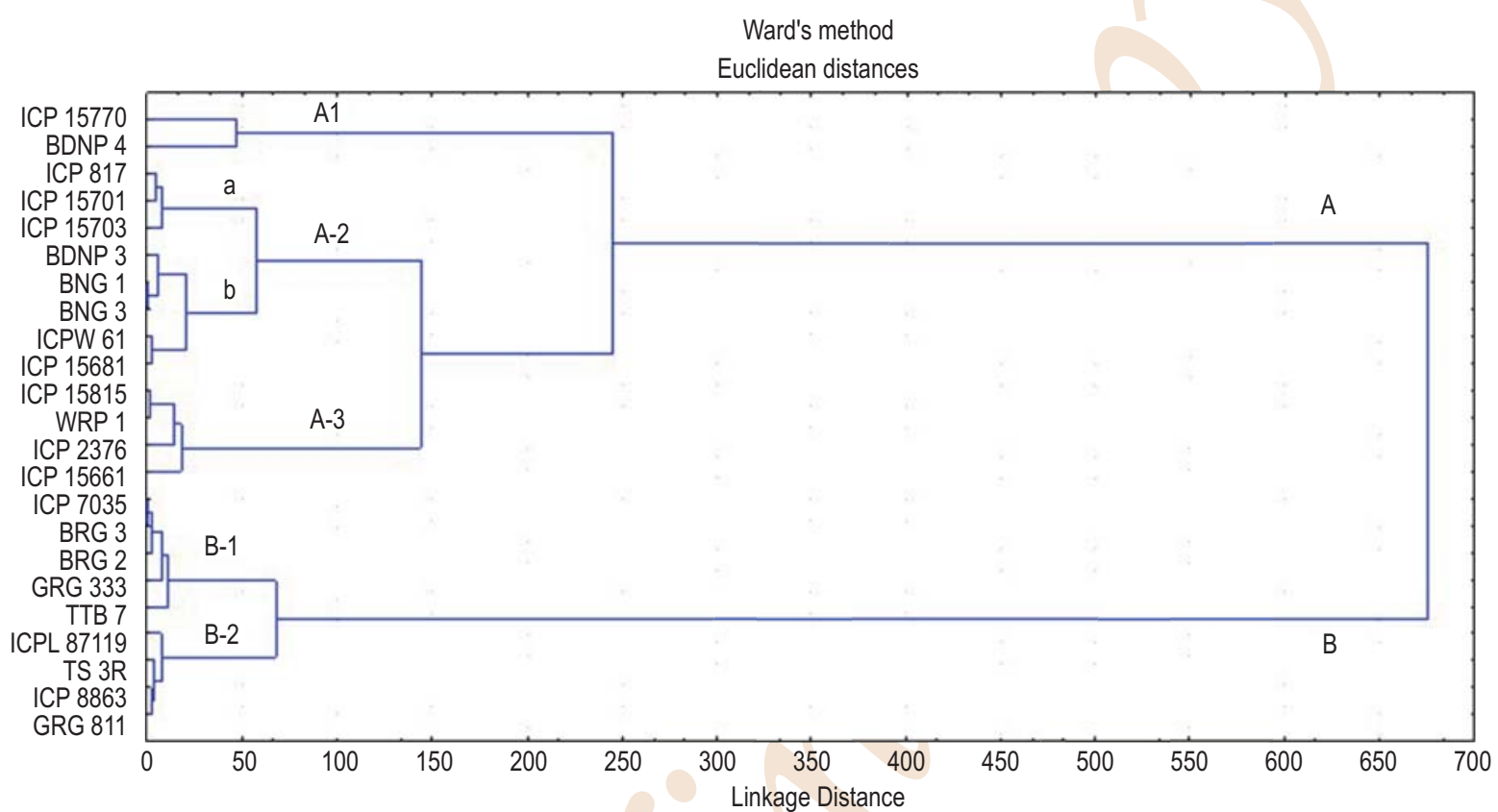

Fig. 2 : Dendrogram for 23 pigeonpea genotypes based on TNLS, TLLS, SLA and SLW data

SLW (5.87 $\mathrm{mg} \mathrm{cm}^{-2}$ ) and LCC (41.42), all the cultivars had lower mean values for LT, UEPT, LEPT, UCWC, LCWC, TLUS, TLLS and SLA as compared to wild species. These differences indicated that wild genotypes have adapted strong leaf structural barriers against herbivores. Ganapathy et al. (2012) reported that leaf leatheriness features attributing to leaf thickness is mainly responsible for vector mediated resistance to SMD in pigeonpea.

Reddy et al. (1995) reported SMD resistant pigeonpea genotypes with thicker cuticle and epidermal cell wall compared to susceptible genotypes. When all the upper and lower surface features were compared within the cultivars and wild genotypes, all the cultivars showed higher mean values for UEPT $(36.59 \mu \mathrm{m})$, UCWC $(5.02 \mu \mathrm{m})$, TNLS (28.42) and TLLS (127.96 $\mu \mathrm{m})$. Similarly, wild genotypes showed higher mean values for same traits i.e., UEPT $(48.87 \mu \mathrm{m})$, UCWC $(6.00 \mu \mathrm{m})$, TNLS (10.75) and TLLS $(215.19 \mu \mathrm{m})$. These results suggested that trichome number and length on lower surface of leaf may influence mite population.
Since, mite population in pigeonpea are concentrated towards the petiole end of young leaves and more than $90 \%$ of mites occur on the lower surface of leaves.

Among the twelve leaf micro-morphological features compared between cultivars and wild. The major differences were noticed for trichome traits. Densities of trichome on epidermal surface were the main factors correlating with resistance to herbivory (Simmons and Gurr, 2005). In pigeonpea, five types of trichomes, three glandular (types A, B and E) and two nonglandular (C and D Type) were reported (Romeis et al., 1999). Non-glandular trichomes were found to physically obstruct the movements of herbivorous (Kennedy, 2003).

All the cultivars (C. cajan) showed a high number of trichomes (>24) on leaf surfaces compared to wild accessions $(<11)$. It confirmed the earlier findings that $C$. cajan had higher densities of trichomes than wild species $C$. platycarpus and $C$. 


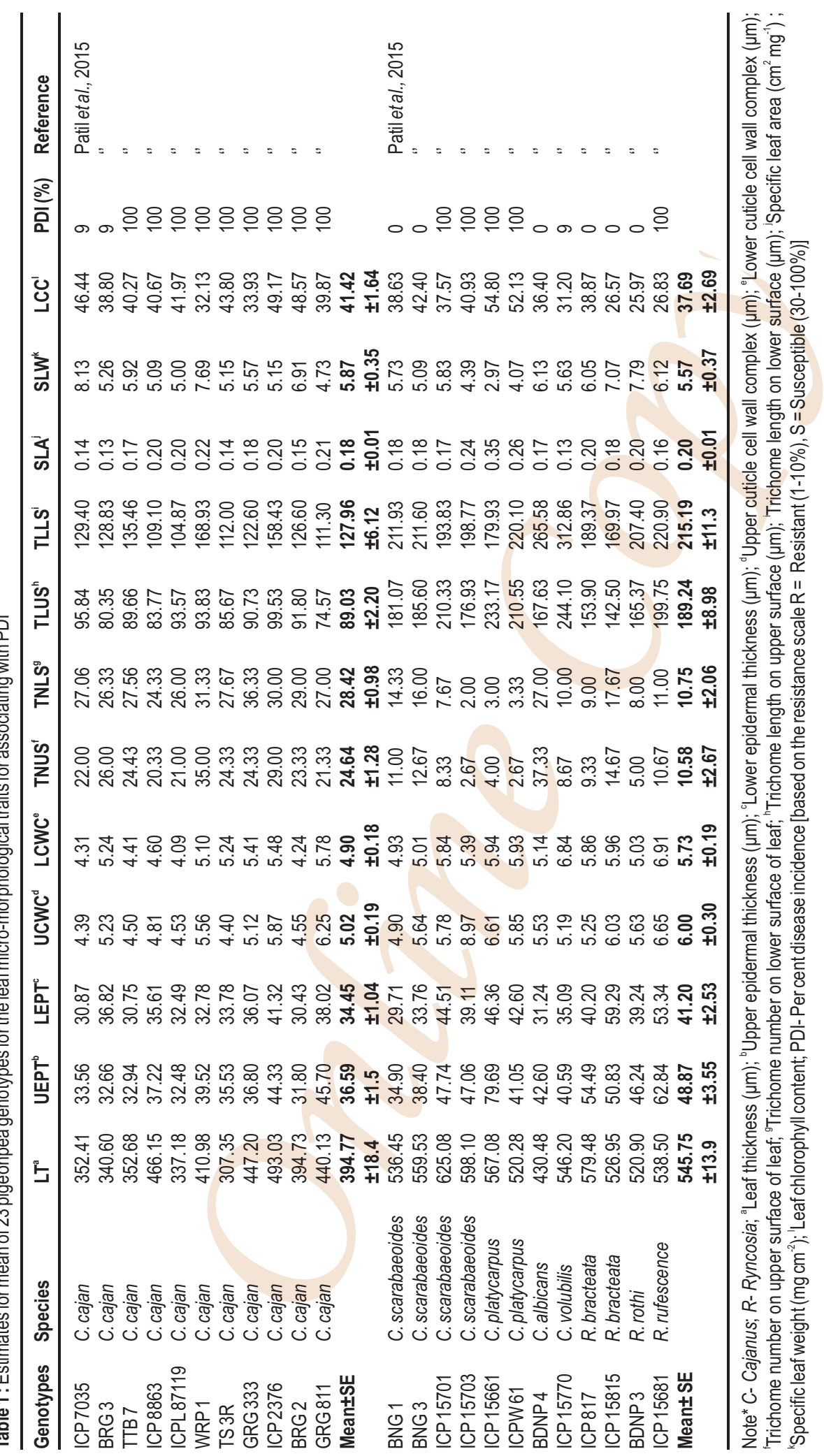


Table 2: Significance of t-test and correlation of leaf micro-morphological traits with SMD incidence in three groups of pigeonpea

\begin{tabular}{|c|c|c|c|c|c|c|c|c|c|c|c|c|}
\hline \multirow{3}{*}{$\begin{array}{l}\text { Leaf micro- } \\
\text { morphological } \\
\text { features }\end{array}$} & \multicolumn{4}{|c|}{ Cultivars } & \multicolumn{4}{|c|}{ Wild } & \multicolumn{4}{|c|}{ Cultivar and wild } \\
\hline & \multicolumn{3}{|c|}{ Mean } & \multirow{2}{*}{$\begin{array}{l}\text { Correlation } \\
\text { with PDI }\end{array}$} & \multicolumn{3}{|c|}{ Mean } & \multirow{2}{*}{$\begin{array}{l}\text { Correlation } \\
\text { with PDI }\end{array}$} & \multicolumn{3}{|c|}{ Mean } & \multirow{2}{*}{$\begin{array}{l}\text { Correlation } \\
\text { with PDI }\end{array}$} \\
\hline & (2R) & (9S) & P-value & & (7R) & (5S) & P-value & & (9R) & (14S) & P-value & \\
\hline $\mathrm{T}(\mu \mathrm{m})$ & 346.51 & 405.49 & 0.024 & 0.391 & 528.57 & 569.81 & 0.151 & 0.448 & 488.11 & 464.17 & 0.557 & -0.17 \\
\hline UEPT $(\mu \mathrm{m})$ & 33.11 & 37.37 & 0.036 & 0.359 & 44.01 & 55.68 & 0.179 & 0.476 & 41.58 & 43.91 & 0.599 & 0.073 \\
\hline LEPT $(\mu \mathrm{m})$ & 33.84 & 34.58 & 0.855 & 0.086 & 38.36 & 45.19 & 0.160 & 0.385 & 37.36 & 38.37 & 0.776 & 0.044 \\
\hline $\operatorname{UCWC}(\mu \mathrm{m})$ & 4.81 & 5.06 & 0.651 & 0.161 & 5.45 & 6.77 & 0.092 & $0.623^{*}$ & 5.31 & 5.67 & 0.335 & 0.159 \\
\hline LCWC ( $\mu \mathrm{m})$ & 4.78 & 4.93 & 0.818 & 0.106 & 5.54 & 6.00 & 0.234 & 0.423 & 5.37 & 5.31 & 0.859 & -0.031 \\
\hline TNUS & 24.00 & 24.79 & 0.816 & 0.065 & 14.10 & 5.67 & 0.048 & -0.562 & 16.30 & 17.96 & 0.803 & 0.068 \\
\hline TNLS & 26.70 & 28.80 & 0.122 & 0.261 & 14.57 & 5.40 & 0.011 & $-.723^{* *}$ & 17.27 & 20.44 & 0.729 & 0.086 \\
\hline TLUS $(\mu \mathrm{m})$ & 88.10 & 89.24 & 0.911 & 0.063 & 177.17 & 206.15 & 0.090 & 0.551 & 157.37 & 130.99 & 0.259 & -0.251 \\
\hline TLLS $(\mu \mathrm{m})$ & 129.12 & 127.70 & 0.856 & -0.028 & 224.10 & 202.71 & 0.318 & -0.201 & 202.99 & 154.49 & 0.054 & $-.456^{*}$ \\
\hline $\operatorname{SLA}\left(\mathrm{cm}^{2} \mathrm{mg}^{-1}\right)$ & 0.14 & 0.18 & 0.008 & $.639^{*}$ & 0.17 & 0.24 & 0.132 & 0.490 & 0.17 & 0.20 & 0.039 & 0.328 \\
\hline $\mathrm{SLW}(\mathrm{mg}) \mathrm{cm}^{-2}$ & 7.43 & 5.69 & 0.038 & $-.615^{*}$ & 6.00 & 4.68 & 0.099 & -0.473 & 6.32 & 5.33 & 0.054 & -0.341 \\
\hline LCC & 42.62 & 41.15 & 0.764 & -0.109 & 34.29 & 42.45 & 0.197 & 0.436 & 36.14 & 41.62 & 0.094 & 0.367 \\
\hline
\end{tabular}

Note* R- Resistant genotypes; S- Susceptible genotypes P-Probability of significance for t-test; LT-Leaf thickness ( $\mu$ m); UEPT-Upper epidermal thickness $(\mu \mathrm{m})$; LEPT-Lower epidermal thickness $(\mu \mathrm{m})$; UCWC-Upper cuticle cell wall complex $(\mu \mathrm{m})$; LCWC-Lower cuticle cell wall complex $(\mu \mathrm{m})$; TNUS-Trichome number on upper surface of leaf; TNLS-Trichome number on lower surface of leaf; TLUS-Trichome length on upper surface $(\mu \mathrm{m})$; TLLSTrichome length on lower surface $(\mu \mathrm{m})$; SLA-Specific leaf area $\left(\mathrm{cm}^{2} \mathrm{mg}^{-1}\right)$; SLW-Specific leaf weight $\left(\mathrm{mg} \mathrm{cm}^{-2}\right)$; LCC-Leaf chlorophyll content; PDI-Per cent disease incidence

scarabaeoides (Romeis et al., 1999). Since, most of cultivars are susceptible to Bengaluru isolate of SMD and mean trichome length noticed was lower than the wild accessions (Patil et al., 2015). Trichrome length in cultivars may be influenced by favoring multiplication of mites, which needs to be further confirmed in relation to mite population. A positive correlation was reported between spotted spider mite population and high hair density on hop leaves (Peters and Berry, 1980). Similarly, a positive correlation between density of trichomes and oviposition of whitefly has been reported in cotton revealing trichomes that generate a microclimate that is more favourable to oviposition by B. Tabaci(Butter and Vir, 1989).

In contrast to cultivars, all the wild genotypes showed higher mean trichrome length and most of the SMD resistant genotypes identified were belonged to wild genotypes (Patil et al., 2015). Kumar et al. (2005) identified 15 SMD resistant pigeonpea accessions, through graft inoculation method proved these accessions did not support mite multiplication and governing vector resistance. These results speculate the negative influence of trichrome on mite population in wild accessions, which needs to be confirmed. Jackai and Oghiakhe (1989) demonstrated trichomes and phytochemicals were responsible for resistance to pod borer in wild cowpea TVnu-72 and TVnu-73 compared to the susceptible variety IT $84 \mathrm{E}-124$.

Association of leaf micro-morphological features with disease incidence : The mite population is known to be highly influenced by environmental conditions. Dipshikha et al. (2013) reported average temperature of about $20-30^{\circ} \mathrm{C}$ prevailing in the month of April is congenial for the multiplication of mite in pigeonpea (>18.3 mites per plant). Lakshmikantha and Prabhuswamy (2002) reported positive correlation for population of $A$. cajani and incidence of sterility mosaic disease in pigeonpea. Therefore, data on SMD responses were employed for association analysis with leaf micro-morphological traits. Kim et al. (2011) reported trichome density of main stem is tightly linked to pepper mottle virus (PepMoV) resistance in chili pepper (Capsicum annuum) and two QTLs (Pep1 and Pep2) for trichrome enhancing locus were identified for PepMoV resistance. Similarly, resistance to $B$. tabaci transmitting Begomovirus in pepper is mainly mediated by morphological traits, such as leaf trichomes and leaf thickness (Firdaus et al., 2011). There is no information available on correlation of mite population with leaf micro-morphological traits in pigeonpea. However, correlation was studied between per cent pod damage caused by pigeonpea spotted pod borer (Maruca vitrata) with trichome density, trichome length on leaves and pods, and revealed a significant negative correlations (Sunitha et al., 2008). Similarly, Oghiakhe et al. (1991) in cowpea and Peter (1995b) in pigeonpea crops reported significant negative correlations between trichome density and pod borer damage.

In order to identify an important leaf micro-morphological trait that imparts resistance to PPSMV transmitting mite vector, statistical significance was tested for mean trait values of resistant and susceptible groups based on t-test and Pearson's correlation. Paired t-test was performed on trait means obtained by grouping resistant (2) and susceptible cultivars (9), resistant (7) and susceptible wild (5), and for both cultivar and wild (9 
i. Cultivars (100\% grouped correctly)
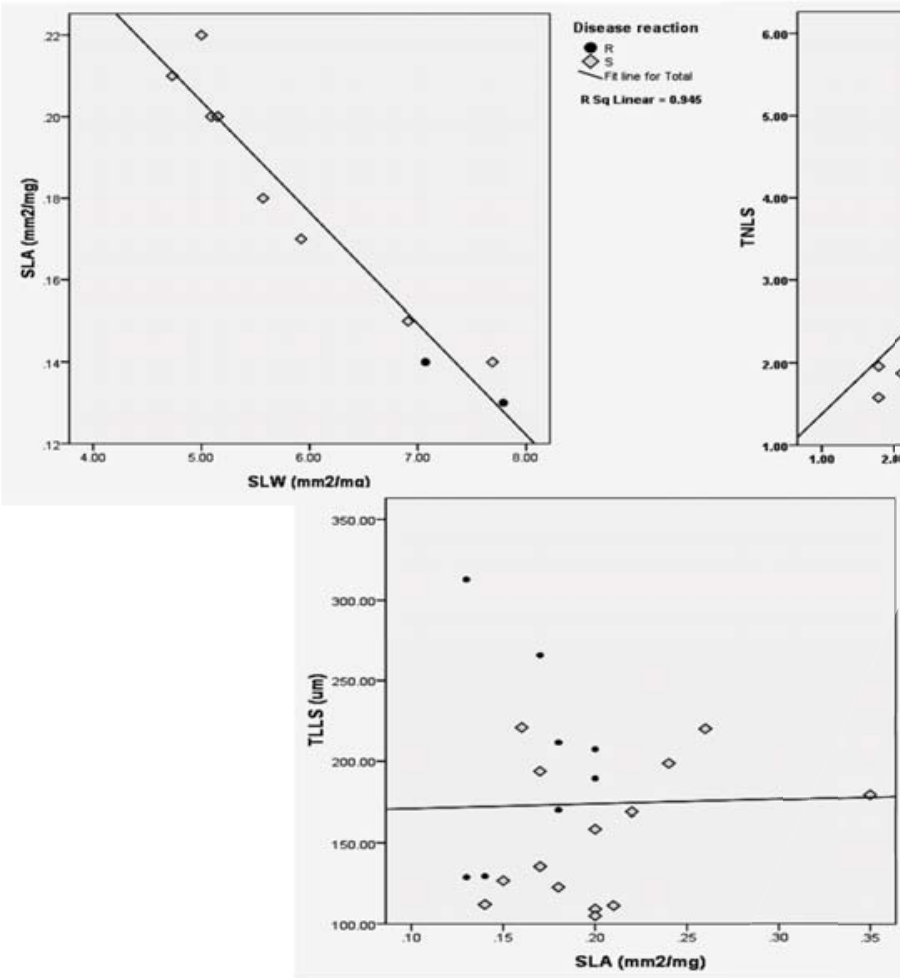

ii. Wild relatives $(83.3 \%$ grouped correctly)

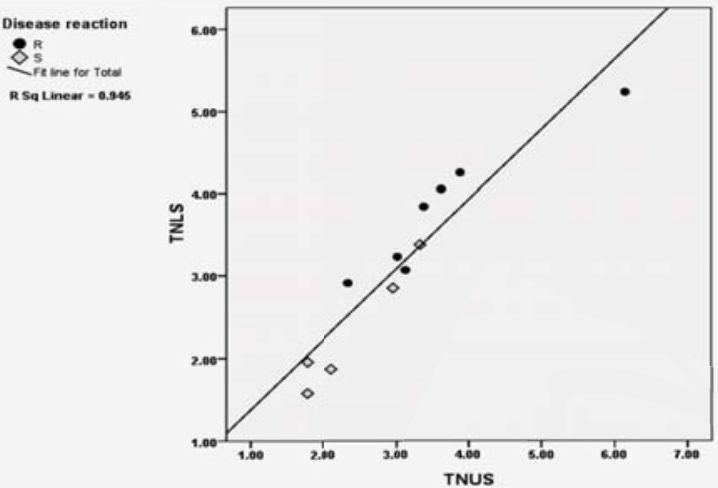

iii. Both cultivars and wild $(76.6 \%$ grouped correctly)

Diseas in ine for toul

Fig. 3 : Scatter plot showing discrimination of resistant and susceptible pigeonpea genotypes based on important leaf micro-morphological tarits with high discrimination function: (i) Cultivars; (ii) Wild genotypes iii. Both cultivars and wild

resistant and 14 susceptible). Significant mean differences were observed for LT, UEPT, SLA and SLW within resistant and susceptible cultivars. Similarly for wild, TNUS and TNLS were differed significantly. Whereas, across the genotypes SLA and TLLS were found be significant (Table 2). Pearson's correlation revealed, significant positive and negative correlation of SLA and SLW with PDI in cultivars. Taggar and Gill (2012) observed leaf area, lamina thickness and trichome length were significantly and positively correlated with whitefly (Bemisia tabaci) eggs, nymphs and adults in black gram varieties.

In the wild relatives of pigeonpea, TNLS and UCWC were found significant with negative and positive correlation with PDI. Chattopadhyay et al. (2011) employed student's t-tests and Pearson's correlation for association of leaf micro-morphological characters with resistance to powdery mildew in resistant and susceptible mulberry (Morus spp.) germplasm groups. They found statistical significance $(P<0.01)$ for stomatal index, stomatal area, trichome density and were negatively correlated with powdery mildew disease severity. In both cultivars and wild, TLLS was found significant and negatively correlated with PDI that was mite infestation. Shakoor et al. (2010) reported length of leaf hair has negative correlation with tomato phytophagous mites (Acari) population. Since, long hairs were not preferred by mites because these produces hindrance in mite movement and impairing mite pest population as they become unable to take their mouth parts at the feeding sites (Pavlova and Egamberdiev, 1990).

Based on the combined results of t-test and correlation, resistance cultivars with lower mean SLA $\left(0.14 \mathrm{~cm}^{2} \mathrm{mg}^{-1}\right)$ and higher SLW $\left(7.43 \mathrm{mg} \mathrm{cm}^{-2}\right)$ compared to susceptible $\left(0.18 \mathrm{~cm}^{2}\right.$ $\left.\mathrm{mg}^{-1}, 5.69 \mathrm{mg} \mathrm{cm}^{-2}\right)$. Whereas in wild, higher mean TNUS (14.10) and TNLS (14.57) was observed for resistant lines compared to susceptible 5.67 and 5.40 . However, in both cultivars and wild higher mean TLLS $(202.9 \mu \mathrm{m})$ was observed for resistant lines compared to susceptible $(154.49 \mu \mathrm{m})$. These results were further confirmed with discriminant analysis.

Discriminant functions : Discriminant analysis revealed the traits which were significant for both t-test and correlation in relation to PDI were having higher discrimination functions. In cultivars, SLA and SLW, in wild TNUS and TNLS, and in both cultivars and wild TLLS and SLA showed higher discriminant functions. Based on the canonical discriminant function 
coefficients obtained for each of the groups following functions was developed.

Cultivars discriminant function $(\mathrm{y})=45.0(\mathrm{SLA})+0.188(\mathrm{SLW})-9.064$

Wild relatives discriminant function(y) $=-1.661$ (TNUS) +3.002 (TNLS) -4.446

Both cultivars and wild $(\mathrm{y})=0.014$ (TLLS) $-16.456(\mathrm{SLA})+0.495$

Using these functions, most of the resistant and susceptible pigeonpea cultivars were classified with $100 \%$ accuracy, wild genotypes into $83.3 \%$ and both cultivars and wild into $76.6 \%$ in scatter plot (Fig. 3). These functions would be useful for identifying SMD resistant pigeonpea genotypes. Similarly, discriminant functions were developed based on root anatomical traits to identify fusarium wilt resistant pigeonpea genotypes (Mandal et al., 2013). Canonical discriminant analysis was also used to identified resistance traits such as trichome density, leaf toughness and stem sugar content for discriminating maize genotypes into resistance and susceptible categories for stem borers (Chilo partellus) (Munyiri et al., 2013; Wanja et al., 2015).

A strong association of SLA, SLW, TNLS and TLLS with $\mathrm{PDI}$ were used to partition SMD disease responsiveness genotypes through hierarchical cluster analysis. Twenty three pigeonpea genotypes were grouped into two major clusters (A and B) with a wide linkage distance of 667 (Fig. 2). The major cluster A constitute all wild accessions and was further divided into three sub-clusters (A-1, A-2 and A-3). Major cluster $B$ constituted all cultivars and divided in to sub-clusters B-1 and B-2. Sub-cluster A-2 was further divided in to sub-groups ' $a$ ' and ' $b$ ' respectively. Similarly, Chattopadhyay et al. (2011) reported strong association of stomatal index, stomatal area and trichome density with resistance to powdery mildew in mulberry and these traits were used to partition 30 accessions through hierarchical cluster analysis.

The cluster analysis clearly separated cultivars from wild genotypes. It also reflected wide genetic variability among wild accession compared to cultivars. These results were in agreement with results as observed for 70 pigeonpea based on leaf features (Patil et al., 2015). Since, trichomes features such as their structure, orientation, density and length had been well correlated with reduced insect damage in several crops (Peter et al.,1995a). Here, we performed cluster analysis based on TNLS and TLLS, which were presumed to be responsible for vector resistance. Results revealed grouping of genotypes is comparable to as observed based on taking all the four features for vector resistance viz., SLA, SLW, TNLS and TLLS (data not shown). Therefore, grouping of resistant genotypes in different cluster can be related to their TNLS and TLLS which helps in selecting parents for crossing program. The most of wild genotypes, which were resistant having higher mean trichome numbers and length $(14.5,224 \mu \mathrm{m})$. Sharma et al. (2009) reported higher densities of non-glandular trichomes on the wild relatives of pigeonpea act as a physical barrier to feeding by the pod borer larvae. Most of the resistant cultivars showed lower mean trichome number (26.7) and higher trichome length (129.12 $\mu \mathrm{m})$. Afzal and Bashir (2007) reported predatory mites (cunaxidae) population decreases with increase in hair length in

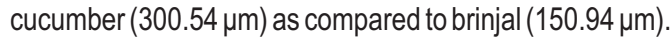

These results possibly help in understanding relation of these traits with vector resistance. The information generated from this study would help in developing novel breeding strategies to combine both vector and host resistance in pigeonpea cultivars against SMD resistance.

\section{Acknowledgment}

Authors would like to acknowledge the University of Agricultural Sciences (UAS), GKVK, Bengaluru, India for providing all the logistical support to carry out this research work.

\section{References}

Afzal, M. and M.H. Bashir: Influence of certain leaf characters of some summer vegetables with incidence of predatory mites of the family cunaxidae. Pakistan J. Bot., 39, 205-209 (2007).

Bernays, E.A. and R.F. Chapman: Host plant selection by phytophagous insects. Springer US Publisher, New York, p.312 (1994).

Brault, V., M. Uzest, B. Monsion, E. Jacquot and S. Blanc: Aphids as transport devices for plant viruses. Comptes. Rendus Biol., 333, 524-538 (2010).

Butter, N.S. and B.K. Vir: Morphological basis of resistance in cotton to the whitefly Bemisia tabaci. Phytopara., 17, 251-261 (1989).

Chattopadhyay, S., K.A. Ali, S.G. Doss, N.K. Das, R.K. Aggarwal, T.K. Bandopadhyay, A. Sarkar and A.K. Bajpai: Association of leaf micro-morphological characters with powdery mildew resistance in field-grown mulberry (Morus spp.) germplasm. AoB Plants, plr002 doi:10.1093/aobpla/plr002 (2011).

Chen, X., V. Ben, R.G.F. Visser, R.A.A. Van der Vlugt and C. Broekgaarden: High throughput phenotyping for aphid resistance in large plant collections. Plant Methods, 8, 33 (2012).

Dipshikha, K., S. Seweta, N.B. Chandra, V.B. Chauhan and R.N. Singh: Correlation between mite population (Aceria cajani) and environmental factors causing sterility mosaic disease of pgeonpea. Int. J. Life Sci., 1, 228-232 (2013).

Durmuşkahya, C., A. Yurdanur and C. Ozdemir: Ecology, anatomy and morphology of Orchis spitzelii in Turkey. J. Env. Biol., 36,177-184 (2015).

FAOSTAT: Food and Agriculture Organization of United Nations. http://faostat.fao.org. (2014).

Firdaus, S., A. Van Heusden, A. Harpenas, E.D.J. Supena, R.G.F. Visser and B. Vosman: Identification of silverleaf whitefly in pepper. Plant Breed., 130, 708-714 (2011).

Fordyce, J.A. and A.A. Agrawal: The role of plant trichomes and caterpillar group size on growth and defence of the pipevine swallow tail Battus phineor. J. Anim. Ecol., 70, 997-1005 (2001).

Ganapathy, K.N., M. ByreGowda, B.C. Ajay, S.C. Venkatesha, B.N. Gnanesh, S.S. Gomashe, P. Babu, G. Girish, P.S. Prasad, G.N. Veerakumar and J.V. Patil: Inheritance studies of sterility mosaic 
disease (SMD) resistance in vegetable type pigeonpea (Cajanus cajan (L.) Millsp.). Aus. J. Crop Sci., 6, 1154-1158 (2012).

Gnanesh, B.N., A. Bohra, M. Sharma, M. Byregowda, S. Pandey, V. Wesley, R.K. Saxena, K.B. Saxena, P.B. Kavikishore and R.K. Varshney: Genetic mapping and quantitative trait locus analysis of resistance to sterility mosaic disease in pigeonpea Cajanus cajan (L.). Millsp. Field Crops Res., 123, 53-61 (2011).

Gucel, S.: Morphology, anatomy and cytology of critically endangered endemic Asperula daphneola from, West Anatolia, Turkey. J. Env. Biol., 36, 129-132 (2015).

Harrison, B.: Virus variation in relation to resistance-breaking in plants. Euphytica, 124, 181-192 (2002).

Jackai, L.E.N. and S. Oghiakhe: Pod wall trichomes and resistance of two wild cowpea, Vigna vexillata accessions to Maruca testulalis (Geyer) (Lepidoptera: Pyralidae) and Clavigralla tomentosicollis Stal (Hemiptera : Coreidae). Bull. Entomol. Res., 79, 595-605 (1989).

Kennedy, G.G.: Tomato, pests, parasitoids and predators: Tritrophic interactions involving the genus Lycopersicon. Ann. Rev. Entomol., 48, 51-72 (2003).

Kim, H.J., J.H. Han, S. Kim, H.R. Lee, J.S. Shin, J.H. Kim, J. Cho, Y.H. Kim, H.J. Lee, B.D. Kim and D. Choi: Trichome density of main stem is tightly linked to PepMoV resistance in chilli pepper (Capsicum annuum L.). Theor. Appl. Genet., 122, 1051-1058 (2011).

Krips, O.E., P.W. Kleijn, P.E.L. Willems, G.J.Z. Gols and M. Dicke: Leaf hair influence searching efficiency and predation rate of the predatory mite Phytoseiulus persimilis (Phytoseiidae: Acarina). Exp. Appl.Acarol., 23, 119-131(1999).

Kulkarni, N.K., A.S. Reddy, P.L. Kumar, J. Vijaynarasimha, K.T. Rangaswamy, V. Muniyappa, L.J. Reddy, K.B. Saxena, A.T. Jones and D.V.R. Reddy: Broad-based resistance to pigeonpea sterility mosaic disease in the accessions of Cajanus scarabaeoides (L.) Benth. Indian J. Plant Protect., 31, 6-11 (2003).

Kumar, P.L., T.K.S. Latha, N.K. Kulkarni, N. Raghavendra, K.B. Saxena, F. Waliyar, K.T. Rangaswamy, V. Muniyappa, S. Doraiswamy and A. Teifion: Broad based resistance to pigeonpea sterility mosaic disease in wild relatives of pigeonpea (Cajanus phaseoleae). Ann. Appl. Biol., 146, 371-379 (2005).

Kumar, P.L., A.T. Jones and D.V.R. Reddy: A novel mite transmitted virus with a divided RNA genome closely associated with pigeonpea sterility mosaic disease. Phytopathology, 93, 71-81 (2003).

Lakshmikantha, B.P. and H.P. Prabhuswamy: Reaction of pigeonpea varieties to mite (Aceria cajani Channabasavanna) transmitting sterility mosaic disease. Plant Prot. Bull., 54, 6-7 (2002).

Mandal, A.K., P. Sinha and S. Banik: Root anatomical parameters for identification of Fusarium wilt resistant and susceptible lines of pigeonpea. Indian Phytopathology, 66, 361-365 (2013).

Munyiri, S.W., S.N. Mugo, M. Otim, J.K. Mwololo and P. Okori: Mechanisms and sources of resistance in tropical maize inbred lines to Chilo partellus stem borers. J. Agric. Sci., 5, doi:10.5539/jas.v5n7p51 (2013).

Oghiakhe, S., L.E.N. Jackai and W.A. Makanjuola: Cowpea plant architecture in relation to infestation and damage by the legume pod-borer, Maruca testulalis (Geyer) (Lepidoptera: Pyralidae)
Effect of canopy structure and pod position. Insect Sci. Appl., 12, 193-199 (1991).

Patil, P.G., M. Byregowda, H.S. Vimarsha, C.M. Keerthi, P.J. Kundur and H.E. Shashidhar: Genetic variability on leaf morpho-anatomical traits in relation to sterility mosaic disease (SMD) resistance in pigeonpea. Aus. J. Crop Sci., 9, 621-628 (2015).

Pavlova, G. and Egamberdiev: Cultivars resistance to Tetranychus urticae. Rev. Agric. Ent., 80, 597-599 (1990).

Peter, J.A., T.G. Shanower and J. Romeis: The role of plant trichomes in insect resistance: A selective review. Phytopathology, 7, 41-63 (1995a).

Peter, J.A.: Pigeonpea trichomes a promising source for pod borer resistance. IPM and IRM News letter. Legume Crops Asia., 2, 5-4 (1995b).

Peters, K.M. and R.E. Berry: Effect of hop leaf morphology on two spotted spider mite. J. Econ. Entomol., 73, 235-238 (1980).

Reddy, M.V. and Y.L. Nene: Estimation of yield loses in pigeonpea due to sterility mosaic. In: Proc. Int. Workshop on pigeonpea, ICRISAT Centre, India, p. 322 (1981).

Reddy, M.V., T.N. Raju and J.M. Lenne: Diseases of pigeonpea. In: The pathology of food and pasture legumes (Eds.: D.J. Allen and J. M. Lenne). CAB-ICRISAT, pp. 517-558 (1998).

Reddy, M.V., V.K. Sheila, A.K. Murthy and N. Padma: Mechanism of resistance to Aceria cajani in pigeonpea. Int. J. Trop. Plant Dis., 13, 51-57 (1995).

Romeis, J., T.G. Shanower and A.J. Peter: Trichomes on pigeonpea [Cajanus cajan (L.) Millsp.] and two wild Cajanus spp. Crop Sci., 39, 564-569 (1999).

Shakoor, A., M.A. Sabri, M. Afzal and M.H. Bashir: Role of plant morphological characters towards resistance of some cultivars of tomato against phytophagous mites (Acari) under green house conditions. Pak. J. Life Soc. Sci., 8, 131-136 (2010).

Sharma, H.C., E.G. Sujana and E.D. Manohar Rao: Morphological and chemical components of resistance to pod borer, Helicoverpa armigera in wild relatives of pigeonpea. Arthro. Plant Interac., 3 , 151-161 (2009).

Sharma, M., R. Ghosh and S. Pande: Multi-environment field testing to identify broad, stable resistance to sterility mosaic disease of pigeonpea. J. Gen. Plant Pathol., 81, 249-259 (2015).

Simmons, A.T. and G.M. Gurr: Trichomes of Lycopersicon species and their hybrids: Effects on pests and natural enemies. Agric. Forest Entomol., 7, 265-276 (2005).

Sunitha, V., G.V. Ranga Rao, K. Vijaya Lakshmi, K.B. Saxena, V. Rameshwar Rao and Y.V.R. Reddy: Morphological and biochemical factors associated with resistance to Maruca vitrata (Lepidoptera: Pyralidae) in short duration pigeonpea. Int. J. Trop. Insect Sci., 28, 45-52 (2008).

Taggar, G.K. and R.S. Gill: Preference of whitefly, Bemisia tabaci, towards black gram genotypes: Role of morphological leaf characteristics. Phytopara., 40, 461-474 (2012).

Wanja, M.S., M.S. Ngure and M.J. Kyalo: Mechanisms and levels of resistance in hybrids, open pollinated varieties and landraces to Chilo partellus maize stem borers. Int. Res. J. Agric. Sci. Soil Sci., 5, 81-90 (2015). 